\title{
HERODOTUS AND LYRIC POETRY
}

\author{
STEPHANIE WEST \\ Hertford College, Oxford
}

\begin{abstract}
RESUMO: A fim de oferecer um breve esboço de alguns aspectos do uso da poesia lírica feito por Heródoto, restrinjo-me à poesia mélica. Começo pelas alusões explícitas e, daí, passo a algumas passagens em que a fonte de Heródoto deve ter sido a poesia lírica - e mesmo a poesia lírica grandiosa de Baquílides e Estesícoro -, embora ele dissimule isso. Tal investigação revela os princípios e metodologia de Heródoto e, além disso, a difusão da poesia lírica nos tempos do autor, um complemento precioso ao retrato que nos fornece Aristófanes.
\end{abstract}

PALAVRAS-CHAVE: Heródoto; poesia lírica grega; versão racionalizante do mito grego.

In introducing his account of the Spartan tradition about the origins of their dual kingship Herodotus notes (vi 52.1) that what they say is not in agreement with

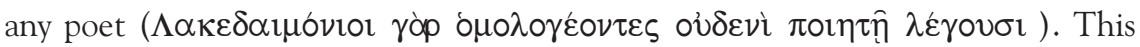
generalizing claim to familiarity with the whole of Greek poetry is disconcerting, but we find something rather similar in his account of the Egyptian gods where, in connection with the Egyptian identification of Demeter with Isis, Artemis with Bubastis (ii 156.6), he argues that Aeschylus must have been influenced by this Egyptian equation when he made Artemis Demeter's daughter, which no earlier poet had done. Obviously Herodotus could not have systematically combed volumes of archaic poetry, but there is, I think, more than bluff to these exhaustive generalizations. Their background is an environment where poetry is of widespread interest and a relatively few (few by modern standards) well known names constitute an informal canon and are much discussed. Poets are still regarded as sources of wisdom, and literary topics figure regularly in conversation. From time to time, we should imagine, Herodotus has raised the question of the peculiar Spartan tradition about the background to their dual kingship and found that no-one could think of any corresponding poetic treatment. This scenario well fits current emphasis on archaic and classical Greece as a 'song culture' - a culture, that is, in which song 
played an important part, with a highly elaborated system of songs for different occasions, where song served to transmit a wide range of knowledge important to the culture of a largely oral society. Poetic celebration inspired emulation, poetic invective deterred antisocial behaviour.

While we may accept that first-hand oral enquiry was basic to Herodotus' investigations, we might expect that for information about the period beyond living memory he owed much to poetry. Indeed, literary celebration affects our view even of events lying within our own experience, making sense of, and imposing a pattern on, what at the time appeared confused and perplexing. Poetic celebration powerfully affects what people judge to be important, a point to be borne in mind in considering Herodotus' principles of selection.

In offering a brief sketch of some aspects of Herodotus' use of lyric poetry I shall restrict myself to melic poetry. I shall start with explicit allusions, and then turn to some passages for which Herodotus' source must have been lyric poetry, and indeed rather grand lyric poetry, though he conceals this. We learn something about his principles and methodology, but also about the diffusion of such poetry in Herodotus' day, a valuable complement to the picture we get from Aristophanes.

\section{The novella of Arion}

That famous poets are regarded as interesting figures in themselves is made clear early in his résumé of Lydian history, with the novella of Arion the Lesbian citharode (I 23f.), saved from pirates by a music-loving dolphin in a manner which strikingly illustrates the workings of divine justice. I shall postpone discussing this episode until the end of this paper, but I would draw your attention to the fragility of its link with its context. The connection is made via Periander, tyrant of Corinth (c.627-587), who is mentioned because of his friendship with Thrasybulus, tyrant of Miletus. At this point in Herodotus' survey Miletus had been besieged for some time by the Lydian king Alyattes, and Thrasybulus gained a significant advantage from intelligence communicated to him by Periander, at whose court Arion spent much time. The connection, as I said, is extremely tenuous, and though Herodotus regards a tendency to digression as nothing to be ashamed of (cf.iv.30.1), his digressions generally have a firmer link with their context. Herodotus will tell us a good deal more about Periander in Book iii, and Arion's adventure could appropriately have been related there. Placed thus early it adds colour to our view of Periander. The association of tyrants and poets is indeed a recurrent motif. Thus 
Lasus of Hermione (PMG 702-6) is mentioned (vii 6.3) on the strength of his detection of literary forgery among Hipparchus' entourage - for us a valuable illustration of Pisitratid cultural policy. Anacreon, likewise, is presented as a court poet enjoying the confidence and esteem of his patron Polycrates (iii 121). His presence at the dining table when the fatal envoy arrives from the Persian satrap Oroetes highlights the sophistication and splendour of the height from which Polycrates was about to fall - and reversals of fortune are a major theme of Herodotus' narrative. No doubt this was part of Samian local tradition, which Herodotus had the opportunity to absorb at an impressionable age. It is interesting that he does not cite Anacreon's poetry for information about Polycrates, though Strabo (xiv $1.18=$ PMG 483) says it was full of references to his patron. Did he tacitly lay it under contribution?

\section{Explicit citations}

\subsection{Sappho}

I pass on to his explicit citations. First Sappho (ii 135). Herodotus is concerned to refute a Greek misconception which associated the pyramid of Mycerinus with the courtesan Rhodopis, who, we are told, was in her heyday in the time of Pharaoh Amasis (570-26). (Herodotus does not offer a reasoned objection, merely assertion - however, that need not concern us.) Rhodopis had come to Egypt under the control of Xanthes the Samian, but was redeemed at a high price by Charaxus, Sappho's brother; when he returned to Mytilene after freeing Rhodopis, Sappho taunted him in song. Thus Herodotus. The sense of family solidarity in archaic Lesbos was evidently not as firm as we might have expected if Sappho could sing compositions which presented her brother in a poor light. For us Sappho is the earliest example of a female author in European literature. Herodotus does not present her as a pioneer. But it is interesting that he describes her as mousopoiovs; the compound is not attested earlier (but cf. ejpopoiovs (ii 120.3; vii 161.3), logopoiovs (ii 134.3; 143.1; v 36.2; 125). What did he see as the difference between this and pointhvs? Euripides seems to have felt that it had feminine connotations (cf.Hipp. 1428f. mousopoiovs . . .parqevnwn mevrimna). Was it suggested by Sappho's own moisovpolos (F 150)?

We have two fragments of Sappho $(5 ; 15 b)$ touching on her brother's indiscretions, but, so far as they go, they manifest sisterly concern, with a prayer to Aphrodite and the Nereids for Charaxus' safe return and fulfilment of his heart's 
desire. Perhaps there was a sharp twist; we should interpret Catullus 11 very differently if we had only the first half. But Charaxus' girl friend is called Doricha, and we do not know on what basis Strabo was able to assure us (xvii 1.33) that this is Herodotus' Rhodopis..

If performance in the symposium was, as seems to be generally accepted, vitally important for the dissemination of monody, we meet a problem where the poet's persona is clearly female. I find it hard to envisage a women's equivalent of the symposium - a regular, institutionalized gathering devoted to having fun, to drinking and song. Until industrialization moved textile production out of the home into the factory, respectable women, even in very prosperous families, were hardly allowed any free time. Of course, the unending tedium of domestic textile manufacture could happily be alleviated by sociable spinning evenings, and these, as folksong collectors in Central and Eastern Europe observed with satisfaction even relatively recently, provided an excellent environment for the transmission of traditional songs and nurtured talent for new composition within familiar conventions. But a spinning circle hardly seems an appropriate milieu for Sappho's songs, and verse composed for purely female gatherings would be unlikely to attract masculine interest. Should we infer that the girl pipers hired to entertain the symposium sometimes sang as well? Or was it acceptable, within symposiastic conventions, for a man to assume a female persona (cf. Alcaeus F 10B, Anacreon PMG 385, Theognis 257-60, 579f., 861-4)?

This reference to Sappho raises a further issue. Herodotus is in no doubt that her verse is to be interpreted autobiographically, and there hardly seems any alternative. Yet nowadays it is a commonplace that we should beware of taking the 'I' of Greek lyric to be the biographical poet. This interpretative trend has perhaps gone too far. The point certainly needs to be borne in mind when we have only part of a poem (as with Archilochus' reference to Gyges' wealth (F19), on which it is fortunate that Aristotle warns us that the speaker is not the poet but Charon the carpenter). But in general archaic poets must have been alert to the danger of constructing a fictitious persona.

\subsection{Alcaeus}

The context of Herodotus' allusion to Alcaeus (v 95) is an account of the circumstances in which Sigeum passed from Mytilenian to Athenian control. The chronology apparently implied is puzzling (and though it is disturbing that Herodotus seems not to have seen the problem, we should not underestimate the difficulty of calibrating the histories of different Greek states before the Ionian 
Revolt), but this does not concern us here. In the course of an engagement in which the Athenians were winning Alcaeus fled; he escaped, but the Athenians got his arms and dedicated them in Athene's temple at Sigeum, as he related in a poem which he sent to his comrade Melanippus. jAlkai 'os oJ pointhvs: the phrase indicates a well known figure, as Aristophanes' references would suggest: cf. Daitaleis (427) F 235 K-A: ai \son dhv moi skovliovn ti labw;n jAlkaivou kajnakrevontos, cf. Thesmo. 160ff. Strabo (13.1.38= Alcaeus F 401a Voigt) quotes two lines; despite some corruption, the sense is clear: "Alcaeus is safe, but the Athenians hung up his weapons in the temple of grey-eyed Athene". Here again, the first person must be autobiographical. We obviously wonder about the relationship of Alcaeus' poem to Archilochus F 5 ajspivdi me; $\mathrm{n}$ Saivwn tis ajgavlletai, a masterpiece of defiant nonchalance. But before we embark on intertextual exploration we should bear in mind that we cannot be certain either that Archilochus' poem was known to Alcaeus or that Archilochus was the only earlier poet to compose some catchy lines on the theme "He who fights and runs away/ Lives to fight another day".

\subsection{Simonides}

Simonides appears twice in Herodotus. Everyone remembers his epitaph for his friend the seer Megistias, steadfast in the face of the death which he foresaw at Thermopylae (vii 228.3). Less often cited is Herodotus' reference to the poet in another death notice, that of the Eretrian general Eualcides, at the battle of Ephesus after the burning of Sardis (v 102.3). Eualcides' victories in the crown games had been celebrated by Simonides (PMG 518). Simonides was, as far as we know, the first to write odes for victors in the crown games (F 506-19); the epinikion was a relatively late development among poetic genres. But though Herodotus likes to record prw'toi euJretaiv (as with Arion's creation of the dithyramb (I 23)), he seems uninterested in Simonides as a literary pioneer.

We should note some other aspects of Simonides' work which Herodotus does not mention. Diodorus (xi 11.6) knew an encomium for those who died at Thermopylae, from which he quotes some lines (PMG 531). Priscian (de metr. Terent. 24) quotes two phrases from Simonides' celebration of the battle of Artemisium (PMG 533), which must have been in lyric metre even though the Suda says it was in elegiacs. The Suda also records a lyric poem on the battle of Salamis (PMG 536). I hardly need to remind you of the elegiac narrative on Plataea 
restored to us by P.Oxy. 3965. It would have been strange if Herodotus ignored these compositions completely.

\subsection{Pindar}

His only reference to Pindar is frankly catachrestic (iii 38.4). Reflecting on Cambyses' foolish disregard for Egyptian religious custom he is moved to consider more generally the importance and legitimacy of their own customs, however bizarre, to different peoples, and cites the mutual horror of Greeks and Indians at one anothers' funerary rites: the Indians are as appalled by the Greek practice of cremation as the Greeks are by funerary cannibalism. Herodotus concludes kai; ojrqw' $s$ moi dokevei Pivndaros poihvsai novmon pavntwn basileva fhvsas ei \nai (F 169 Snell): thus Pindar seems to me to have been right when he said that nomos is king of all.

Thus sentence provides excellent ammunition against those who see no point in reading Herodotus in Greek when so many excellent translations exist. In translating we have to decide whether nomos is 'custom' or 'law'. In the context it has to be 'custom', and Pindar thus provides authoritative support for Herodotus' own ethnographic interests. But of course we have more than the first line of this poem (most probably a dithyramb), and it is clear from what follows that 'law' better suits Pindar's thought. As the first line, this was particularly likely to attract attention; Plato likewise imposes a gross misinterpretation on the poem's opening in the Gorgias (484b). It looks as if the passage had been bandied about in the lively current debate about the relative importance of nomos and phusis. I should hesitate to draw any conclusions about the diffusion of Pindar's work. This is a good example of the way in which snippets of song might become general maxims. This piece of gnomic wisdom is purely ornamental, producing a pleasing closural effect as Herodotus turns from Egyptian/Persian affairs to Samian.

\section{Between lyric poetry and local tradition}

So much for explicit allusion, almost entirely casual notes. Nowadays a historian of archaic Greece may feel that Herodotus did not make the most of his opportunities. But explicit allusion is not the whole story. We now move on to more dangerous ground, where I shall argue that lyric poetry is actually Herodotus' main source, even though he cites local tradition. 


\subsection{The story of Croesus according to Bacchylides}

We have a very striking example in his account of Croesus' escape from death at the fall of Sardis (I 86f.). For Herodotus the reign of Croesus marks the point at which reliable information about the past becomes available, the starting point of the main stream of his narrative (i 5.3). Lydia was important to the sixthcentury Greeks, and Croesus in particular impressed them. Despite the fact that, as Herodotus tells us (i 6.2), he deprived the Asia Minor Greeks of their freedom, he is presented in a very favourable light, and seems to be regarded almost as an honorary Hellene, not really a barbarian. For Pindar Croesus was a supremely happy man who enjoyed both good fortune and a fine reputation and whose generosity with his vast wealth made him a worthy representative of aristocratic ideals (cf. Pyth.i 94f.) From Athens comes a tangible tribute in the form of a marble statue of a youth named after him, dated c.530; the boy must have been named before the Persian conquest removed Croesus from power and brought the Greek cities of Ionia under Persian rule.

The Persian capture of Sardis brings together the main themes developed in Herodotus' history of Lydia. We see the fulfilment of the Delphic oracle foretelling that the penalty for Gyges' assassination of Candaules would be paid in the fifth generation of his descendants (I 13.2) and are reminded of Solon's conversation with Croesus (I 32), a homily on the fragility of human prosperity. This is the climax to which Herodotus' narrative has been leading almost from the start.

No Near Eastern source throws direct light on the end of independent Lydia and Croesus' fate. Though it was long thought that an entry in the Chronicle of Nabonidus for 547 referred to the conquest of Lydia and its king's death, this interpretation is no longer accepted. But even if 547 is a year or so too early, this traditional date cannot be far out.

We have a remarkable illustration of the impression which Croesus' end made on the Greek world in a famous, much reproduced depiction of the king seated on a magnificent funeral pyre, on a red-figure amphora by Myson, dated c.490 and now in the Louvre. Croesus is labelled; robed and garlanded, he hold a libation vessel, and looks calm and contented. A servant, labelled EUQUMOS, is about to light the pyre. Such a historical scene is very unusual in vase painting; very probably the fate of the last Lydian king had been given contemporary relevance by the Ionian Revolt.

By way of exegesis we have Bacchylides, Ode 3, composed to celebrate Hieron's victory in 468 in the chariot race at the Olympic games. Like the vase-painter, 
Bacchylides does something very unusual in taking from the recent past the myth which is an almost invariable element in a victory ode. When Sardis fell to the Persians, he tells us (iii 22-62), the king did not wait to suffer slavery, but had a great pyre heaped up in his palace courtyard, and mounted it, accompanied by his wife and daughters. When it was burning, he prayed to Apollo, and the god responded to his appeal; while Zeus quenched the pyre with a sudden storm, Apollo carried off Croesus and his daughters to the Hyperboreans' earthly paradise at the back of the North Wind, on account of the king's piety, because he was uniquely generous in his gifts to Delphi (di j eujsevbeian o\{ti mevgista qnatw'”n ejs ajgaqevan ajnevpemye Puqwv). In this paranormal rescue the demarcation of divine functions should be noted: Zeus acts in his regular role as a controller of the weather, and the really miraculous element, which Bacchylides highlights a such (a [piston oujdevn, o\{ti qew'-n mevrimna teuvcei), comes with Apollo's intervention. Piety is rewarded, and a story of catastrophe ends in joy. An episode from the recent past is given a standing analogous to that of the stories of the heroic age.

To the historian the conclusion should be clear: after Croesus mounted the funeral pyre, he was never seen again. There are many Near Eastern parallels for a ruler's self-immolation by fire when faced with defeat. We see in Herodotus a similar principle motivating the deaths of Hamilcar at Himera (vii 167) and Boges at Eion (vii 107, cf.113; Thuc.i 98.1). It would have been entirely reasonable for Croesus to choose this course when Persian victory appeared certain, rather than wait to see whether the victor's mercy might extend to a ruler who had waged aggressive war against Persia. This is the tradition which impressed Myson; whether he knew of Apollo's intervention or whether it was a later development in the saga we cannot tell.

This is not of course the story which Herodotus tells. His account lacks the really miraculous element, translation under Apollo's auspices to the happy Hyperboreans. But this fundamental difference is linked with a divergence earlier in the narrative. In Herodotus it is Cyrus who orders the pyre. Herodotus professes uncertainty about his motive (i 86.2): "Perhaps he intended to make a magnificent offering to some god of his, or perhaps he had made a vow and wished to fulfil it, or maybe he had heard that Croesus was a god-fearing man and set him on the pyre to se if any divine power would rescue him from being burnt alive". The third possibility, because it comes last, makes the strongest impression; but this extraordinarily cruel experiment is hardly consistent with the generally favourable presentation of Cyrus (and, as was noted in antiquity (Nicolaus of Damascus (FGrH $90 \mathrm{~F}$ 68.12)) is not easily reconciled with Zoroastrian reverence for fire). It looks 
as if this was devised in the light of the outcome. The alternative suggestions raise problems when Cyrus changes his mind; he ought not thus to abandon a project undertaken in honour of the gods without, at least, promising to offer an equivalent or more valuable substitute. But Herodotus does not really believe in these alternatives.

Nor does the process which leads to Cyrus' change of heart bear serious scrutiny. Croesus, consigned to the burning pyre, recalled Solon's observation that no living man was truly happy, and three times uttered Solon's name. This excited Cyrus' curiosity, and Croesus was induced to relate his encounter with Solon, and how he had come, too late, to appreciate the truth of the Athenian's words. This led Cyrus to regret his decision to burn Croesus alive; but the fire had now got a hold, and attempts to extinguish it failed. (You might think that a serious conversation in these conditions would be impossible.) Then, so the Lydians say ( $\mathrm{i}$ 87.1), Croesus called upon Apollo, and the sunny sky suddenly darkened, and torrential rain put out the fire. Croesus' reputation for piety thus received supernatural endorsement. There is no violation of natural law; it is the timing of the cloudburst which indicates divine intervention, but the god responsible is not Zeus but Apollo. The Lydian king lives on as a pensioner at the Persian court, to give advice (sometimes good, sometimes bad), first to Cyrus and then to his successor, Cambyses. But Herodotus has nothing to say about the old man's death.

Herodotus should not be supposed responsible for extending Croesus' life for twenty years beyond the fall of Sardis. Rumours that a greatly loved or admired figure commonly believed to be dead has really survived - as with Nero, Hitler, and Elvis Presley - often gain solidity with the passage of time. The development of Croesus' legend reflects the fascination for the Greeks of the last of the fabulously wealthy Lydian kings. The circulation of such tales must have convinced Herodotus that Croesus somehow survived the sack of Sardis. The Persian court would have provided a refuge in accordance with his status, and the seclusion of the king and those close to him - a feature which the Greeks regarded as typical of Oriental autocracies (cf.i 99) - would explain why no one ever saw the ex-monarch. He could indeed be supposed to have exercised a civilising influence on the new regime, as empire brought the tough Persians a taste for luxury.

Herodotus' narrative thus rationalizes Bacchylides' and goes beyond it to account for stories of Croesus' survival. The more realistic outcome called for an earlier change. There would have been an unfortunate effect of bathos if the king, having determined on a death of his own devising, was frustrated by a change in the weather. His escape requires another to pronounce the death sentence, and 
this role naturally falls to the conqueror, Cyrus. But neither the motivation for Cyrus' original decision nor the process leading to his change of heart stands up to serious scrutiny.

If we treat Herodotus' account as nearer to the truth than Bacchylides', we have misconceived the relationship between the two. Herodotus, well aware that poets exercise some licence in their presentation, offers a reconstruction of the events which form the basis of Bacchylides' myth. That version must have had the approval of Delphi; the oracle had reason for unease at the downfall of a conspicuous benefactor whom it had apparently encouraged to embark on a disastrous war, and the fantasy of conveyance to an earthly paradise provided a satisfying apologia. Herodotus' rationalizing narrative still leaves the theological element central; in the god's timely response to the pious king's prayer we have the sort of miracle which the fifth-century enlightenment could accept, which indeed reinforced faith in Delphi and its god. The distinctiveness of Herodotus' treatment lies in integrating the glorification of Apollo with validation of Solon's wisdom.

Herodotus, then, is somewhat disingenuous. The Lydian tradition which he cites when he relates Croesus' prayer to Apollo (i 87.1) was not his main source for this episode, if, indeed, it was really his source for any of it. He owed far more to Bacchylides, but this debt is not acknowledged. I do not want to give the impression that this approach to the episode is my own original idea. It was pioneered by Walter Burkert in a Festschrift published in 1986, but not as well known as it should be. Wolf-Hartmut Friedrich, in a paper published in 1998, took a similar line, apparently unaware of Burkert's discussion.

\subsection{The story of Helen according to Stesichorus}

This is not the only place where Herodotus attributes a rationalized version of Greek myth to foreign sources. We may compare the demythologized treatment of the legends of Io, Europa, Medea, and Helen attributed to Persian and Phoenician traditions (in strange concord) in his opening chapters (i 1-5). The legends are not only rationalized but organized into a series of paired abductions highlighting at the outset the principle of reciprocity of pervasive importance for Herodotus' work. There, however, Herodotus expresses agnosticism about the truth of these foreign versions. It is otherwise when he again deals with the story of Helen, in his history of Egypt before the coming of the Greeks in the reign of Psammetichus (ii 142), where he cites as his informants the priests of Hephaestus (i.e.Ptah) at Memphis (ii 112-20). Whereas many of Herodotus' source citations do not 
necessarily imply that he himself spoke to those to whose testimony he appeals, he is quite explicit that he heard this story directly from the Memphite clergy. But the story which he tells is quite plainly a version of Stesichorus' distinctive treatment, which completely freed Helen from blame, claiming that she never went to Troy, but a phantom, an eidolon, went in her stead (PMG 192). Since the publication of P Oxy 2506 (PMG 193) we have known that in Stesichorus, as in Euripides' Helen, she spent the Trojan War in Egypt, with Proteus. In Herodotus the story is given a further twist, cancelling the exculpatory force of Stesichorus' treatment. Certainly Helen did not go to Troy, but she left Sparta with Paris; however, the adulterous pair were frustrated by winds which blew them south to Egypt and the high-minded interference of King Proteus. Helen's failure to reach Troy might be thought to raise doubts about the historicity of the Trojan War itself, which seems absurd if the Trojans did not have Helen at all. But the priests, recounting what had subsequently been learnt from Menelaus, explained that the Greeks had simply not believed the Trojans' protestations that Helen and Menelaus' stolen property were in Egypt and only accepted the truth after they had taken Troy and found that Helen was indeed not there. Herodotus finds this Memphite version very convincing, since, he argues, surely if Helen had been in Troy the Trojans would have returned her to the Greeks, at any rate once there had been a few casualties among Priam's sons. In the Greek refusal to accept the truth, Herodotus maintains, we see a divine force at work to ensure conspicuous punishment appropriate to Paris' sin and the Trojans' complicity in his shocking violation of the customs of guest-friendship.

Herodotus thus seems to be adapting what was certainly regarded as a distinctively Stesichorean version of Helen's story to meet a doubt about the historicity of the Trojan War - part of the widespread contemporary tendency to question traditional beliefs and practices. The story which he tells was certainly no part of Egyptian tradition; it takes extraordinary ingenuity to uphold his good faith here, to postulate an Egyptian with a perversely well-informed interest in Greek mythology who yet rejected an element in Stesichorus' version which might be expected to hold a peculiar appeal for an Egyptian - the phantom, reminiscent of the Egyptian ka. Even if we allowed that hypothesis, it would still be surprising that Herodotus does not comment on the affinity between the Memphite version and Stesichorus'; we might have expected him to hazard the guess that Stesichorus had been influenced by Egyptian ideas, as he does with Aeschylus' view of the relationship between Demeter and Artemis (ii 156.6). 


\section{Conclusion}

We also should discuss Herodotus' account of the foundation of the oracle of Dodona, which he attributes to the priests of Egyptian Thebes (ii 54-7) but which looks like a rationalization of a tradition known from Pindar (F 58, perhaps from a paean to Zeus of Dodona). I would have liked, too, to discuss his use of Pythian 4 in his account of the foundation of Cyrene (iv 145ff.), but that would call for a lecture to itself.

But I think that these instances are enough to show that Herodotus' source citations are not always straightforward. I do not say that they are never truthful, but in the instances which I have discussed they are part of a wider fiction of orality. Bacchylides' victory odes and Stesichorus' lyric epics cannot have been staples of sympotic entertainment. Herodotus knows what he knows of them because texts are available and he has read them. But the prejudice against undue reliance on script which we find in Plato (see especially Phaedrus 274c5 - 275b4) was surely more widespread in the mid-fifth century, and Herodotus' propensity to conceal or disguise his actual sources results, I would argue, from a wish not to appear too bookish (rather as Cicero in his speeches is vague about the source of quotations the provenance of which, as we see from his other works, was perfectly clear to him). It is a commonplace of Herodotean scholarship that we must not judge him by the standards of a modern historian. It should not therefore surprise us if he failed to see how much the provenance of information matters.

I return now to the story of Arion (i 23f.), strikingly irrelevant to its context, the history of Lydia. We get a marvellous picture of the greatest citharode of his day magnificently demonstrating his contempt for death and surviving by what would have been a miracle if it had happened. I take it for granted that a dolphin could not carry an adult any distance, but allow that Herodotus and his contemporaries believed it to be possible. For them the timely arrival of the musicloving dolphin must be as much an indication of divine forces at work as the unexpected cloudburst which saved Croesus from a fiery death. Herodotus cites Corinthian and Lesbian tradition for this story, along with a statue of a man on a dolphin from Taenarum, which he says was dedicated by Arion (though he does not explain how he knew). "It has long been recognized" writes Walter Burkert (Homo Necans (1983), 199) "that this pretty tale has a most specific meaning'. We have an important clue in Herodotus" tribute to Arion as the inventor of the dithyramb, the choral dance honouring Dionysus (diquvrambon prw'ton ajnqrwvpwn tw'n hJmei 's i [dmen poihvsantav te kai; ojnomavsanta kai; didavxanta ejn Korivnqwi). The word diquvrambos occurs already 
in Archilochus (F 120.2); we should probably take Herodotus to mean that Arion established a musical form for what had been a crude folk-dance and introduced mythological subject-matter. An association between Dionysiac dances and dolphins is clear from vase-paintings virtually from Arion's lifetime. It is a likely conjecture that Herodotus' novella is based primarily on cult-song in Dionysus' honour, a kind of foundation myth for the dithyramb. The composition which Aelian (HA xii 45) ascribes to Arion (PMG 939) is highly suggestive, though on grounds of metre and style it is most unlikely that it could have been known to Herodotus. His references to the local traditions of Corinth and Methymna seem to me merely cosmetic, to be salvaged, if they must be, by the hypothesis that literary pseudohistory percolated back to the cities particularly associated with Arion..

The great age of lyric poetry was ending at about the time when Herodotus set to work. Pindar himself was well aware of the power of poetry to gain credence for a version of events which might otherwise be viewed with scepticism (O.1.2832) We have only a fraction of the lyric poetry which Herodotus is likely to have known, and must face the probability that much of what he judged important has left no trace. But it would do not harm to consider the possibility that his narrative draws on poetry rather more and on direct oral testimony rather less than we might on first reading suppose.

WEST, S. Herodotus and lyric poetry.

ABSTRACT: In offering a brief sketch of some aspects of Herodotus' use of lyric poetry I shall restrict myself to melic poetry. I shall start with explicit allusions, and then turn to some passages for which Herodotus' source must have been lyric poetry, and indeed rather grand lyric poetry, though he conceals this. We learn something about his principles and methodology, but also about the diffusion of such poetry in Herodotus' day, a valuable complement to the picture we get from Aristophanes.

KEYWORDS: Herodotus; Greek lyric poetry; rationalized version of Greek myth. 